\title{
HISTORIS BIMBINGAN DAN KONSELING (DEKADE PERGERAKAN PROFESI BIMBINGAN DAN KONSELING)
}

\author{
Hendra Pribadi \\ Universitas Borneo Tarakan/FKIP/Bimbingan dan Konseling \\ hndrafinger@gmail.com
}

\begin{abstract}
ABSTRAK
Bimbingan dan Konseling merupakan pergerakan kemanusiaan bagi negara modern. Profesi Bimbingan dan Konseling memiliki historis dalam karangan rentetan waktu. Kerangka historis pada artikel penelitian ini mengacu pada pergerakan ilmu bimbingan dan konseling dari gambaran tokoh, kondisi dan organisasi mengarah pada profesi dan dinamika keilmuan bimbingan dan konseling dalam dekade abad ke 20. Penelitian ini menggunakan pendekatan metode studi literatur dengan pendekatan perspektif kualitatif emik berorientasi pada analisis deret waktu didasarkan pada pergerakan ilmu bimbingan dan konseling dari tahun 1900 hingga 1990-an.
\end{abstract}

Kata Kunci : Pergerakan, Bimbingan dan Konseling)

\section{PENDAHULUAN}

Bimbingan dan Konseling merupakan gagasan yang istimewa bagi negara modern. Gagasan ini timbul berawal bahwa bimbingan dan konseling dianggap sebagai pergerakan kemanusiaan setelah manusia dihadapkan pada pengalaman kolonialisme, ekspansi industrialisasi, dan periode nasionalisasi (Picchioni, 1980).

Kerangka ilmu bimbingan dan konseling didasarkan kepada pengetahuan filosofis, pengetahuan psikologis, dan pengetahuan sosiologis. pengetahuan filosofis yang digunakan dalam bimbingan (idealisme, pragmatisme, realisme, rasionalisme, dan eksistensialisme) untuk menemukan atau merasakan pendekatan yang sesuai. Begitu pula pengetahuan psikologis (psikoanalisis, behavioristik, kognitif, humanistik) dan pengetahuan sosiologis (kebutuhan, sikap dan penerimaan sosial, identitas diri, keterampilan komunikasi) dalam membentuk dasar dari bimbingan dan konseling

Pergerakan Bimbingan dan Konselkeing digunakan sebagai pokok kalimat dalam melakukan tinjauan kerangka ilmu bimbingan dan konseling.

Profesi Bimbingan dan Konseling memiliki historis dalam karangan rentetan waktu yang melibatkan dinamika masalah pada setiap dekade generasi terakhir pada beberapa literatur, seperti : buku John M. Brewer (1942) berjudul "History of Vocatonal Guidance ", Disertasi Barry dan Wolf (1955) yang berjudul "A History of The Guidance Personal Movement in 
Education" di Universitas Columbia, Buku Eddy Wibowo, Mungin (2018) yang berjudul" Profesi Konseling Abad 21" dan beberapa literatur atau disertasi baik yang sudah diterbitkan dan tidak diterbitkan.

Kerangka historis pada artikel penelitian ini mengacu pada pergerakan ilmu bimbingan dan konseling dari gambaran tokoh, kondisi dan organisasi mengarah pada profesi dan dinamika keilmuan bimbingan dan konseling dari tahun 1900-an hingga 1990-an.

Diharapkan artikel ini dapat memberikan pemahaman tentang berdirinya Bimbingan dan Konseling sebagai keilmuan dilihat dari sudut pandang pergerakan bimbingan dan konseling dalam dekade abad ke 20

\section{METODE PENELITIAN}

Penelitian ini menggunakan pendekatan metode studi literatur dengan pendekatan perspektif kualitatif emik. Pengumpulan data dilakukan dengan teknik studi dokumentasi dan rekaman arsip. Analisis penelitian ini berorientasi pada analisis deret waktu, yakni urutan waktu secara kronologis didasarkan pada kalimat "Pergerakan Ilmu Bimbingan dan Konseling". Metode penelitian ini memberikan perhatian pada pemaknaan atau interpretasi teks berkenaan pada historis didasarkan pada pergerakan Ilmu Bimbingan dan Konseling dari tahun 1910 hingga 1990.

\section{HASIL DAN PEMBAHASAN}

a. Pergerakan ilmu bimbingan dan Konseling tahun 1900 -an (Permulaan Pergerakan Bimbingan)

Secara formatif, permulaan pergerakan bimbingan telah didorong oleh pionir didasarkan pada ide-ide atau pemikiran sosialisme. Adapun pionir yang mempelopori, yakni Frank Parson, Jesse Buttrick Davis, Clifford W. Beers ,Eli Witwer Weaver dan Anna Yeomans Reed. Pada masa ini, pergerakan bimbingan . ilmu bimbingan sudah disadari sebagai suatu konsep. namun ilmu bimbingan tidak memiliki status yang independen hanya program tambahan pada sistem pendidikan.

Frank Parson (14 November 1854 26 September 1908) merupakan tokoh yang menyajikan kerangka konseptual karir dan panutan awal dalam bimbingan hingga diberikan julukan "bapak penggerak Bimbingan". Pemikiran parson dibingkai pada filosofis mutualisme (bagian dari sosialisme). Pada tahun 1905, Parson telah membangun lembaga "vocational bureau" di Boston, komitmen ini untuk membantu remaja yang mengalami transisi dari masa sekolah ke masa bekerja. Bentuk bimbingan parson didasarkan pada analisis diri dalam konteks sosial reformasi. Pada tahun 1909, Monograf yang berjudul "choosing a vocational" dari Frank Parson diterbitkan.

Parson meyakini bahwa kesempurnaan manusia dan pergerakan sosial mengarah pada kesempurnaan dunia. Peristiwaperistiwa ini yang mendorong timbulnya gerakan bimbingan. 
Jesse Buttrick Davis (1871- 3 November 1955) merupakan konselor pertama yang melaksanakan program bimbingan secara sistematis pada lingkungan sekolah di Detroit dari tahun 1897 hingga 1907. Pada tahun 1907, Davis menjabat kepala sekolah pada sekolah menengah, kemudian Davis mendorong para guru bahasa inggris di sekolah untuk menggunakan susunan pelajaran mengarah pada minat karier, pengembangkan karakter, dan komunikasi interpersonal. Selama kurun waktu itu, program bimbingan ini menekankan pada jabatan, seleksi, dan penempatan.

Davis merupakan salah satu pendiri National Vocational Guidance Association (saat ini bernama National Career Development Association) and National Association of Secondary School Principals. Davis menggambarkan bimbingan dilakukan pada nasehat pada siswa tentang nilai moral bekerja keras,cita-cita, kejujuran, dan perkembangan karakter sebagai aset bagi setiap orang dalam dunia kerja. Para kalangan sosial historis menyebutkan bahwa davis merupakan pendorong sosial gospel.

Clifford Whittingham Beers (30 Maret 1876 - 9 juli 1943) dikenal sebagai penggerak kesehatan mental di Amerika Serikat. Pada tahun 1908, Beers telah menulis buku yang berjudul "A Mind That Found Itself " yang berisi tentang riwayat perawatan dan perlakuan yang telah dialami dalam tekanan psikologis pada lembaga kesehatan mental selama masa anak-anak. Buku otobiografi ini menjadi buku penjualan yang terlaris dan masih dicetak. Pergerakan kesehatan mental ini digunakan sebagai pengobatan emosional dan kebutuhan perkembangan dalam metode klinis, sebagaimana ilmu bimbingan menjalankan fungsinya.

Eli Witwer Weaver (5 Agustus 1862- 1 November 1922) dikenal sebagai edukator terbaik dan guru matematika di Sekolah Menengah Umum. Weaver diberi julukan "Bapak Bimbingan Vokasi pada Sekolah Umum. Weaver membentuk komite guru bimbingan pada sekolah di New York. Komite ini bekerja aktif dalam membantu remaja dalam menemukan kemampuan dan belajar menggunakan bakat dalam menjamin ketepatan pekerjaan.

Anna Yeomans Reed (19 September 1871 - 29 Juli 1946) merupakan seorang edukator progresif. Anna memberikan layanan konseling didasarkan pada sosial darwinisme. Anna menyusun pula bimbingan pada kurikulum sekolah. Reed membangun layanan bimbingan pada sekolah di Seattle. Reed meyakini bahwa layanan bimbingan penting sebagaimana pengembangan hasil dari pendidikan. Dalam persaingan yang ketat, orang-orang memerlukan usaha terbaik pada beberapa tugas dalam melihat diri. 


\section{b. Pergerakan ilmu bimbingan dan Konseling tahun 1910 -an (Pergerakan bimbingan pada biro, sekolah dan militer)}

Biro bimbingan yang dibangun masih berlanjut setelah Frank Parson meninggal. Pada tahun 1910, Biro bimbingan pada kepemimpinan baru menawarkan layanan bimbingan kepada publik. Biro bimbingan juga membangun pelatihan guru sebagai konselor. Pada proposal awal layanan bimbingan dinamakan instruksional bagi siswa dalam informasi jabatan, pengembangan layanan penempatan, dan menemukan tindak lanjut informasi. Semua unsur ini (Ketiganya) akan menjadi bagian dari praktik bimbingan modern (Picchioni, Anthony Paul, 1980).

Komite biro bimbingan melaksanakan konferensi nasional bimbingan vokasional pertama pada 15 -16 November 1910 di Boston. Konferensi ini didelegasikan pada spektrum tenaga kerja, industri, bisnis, pekerja sosial, pendidikan dan gerakan kemanusiaan pada bangsa yang maju ( humanitarian impulse of the progresive era ). Konferensi ini menimbulkan minat pada bimbingan ditandai pada kehadiran delegasi dari 45 kota, partisipasi ratusan guru dan partisipasi prosiding yang dilaporkan. Kemudian memutuskan pertemuan konferensi nasional yang kedua di Kota New York dilaksanakan pada 23 26 Oktober 1912. Kesuksesan dari konferensi ini diindikasikan pada laporan bimbingan yang telah dikerjakan oleh para partisipan dan guru di sekolah, seperti jumlah anak yang bekerja 132. 000 di kota
New York, 3/ 4 keluarga tidak mampu membiayai anaknya di Chicago, beasiswa yang diperoleh, rencana pengalaman tryout dan sebagainya.

Konferensi bimbingan vokasional yang ketiga dilaksanakan pada pertemuan nasional sosialisme (komite dengan masyarakat nasional ) yang mendorong pendidikan industri di Grand Rapids dari 21 - 24 Oktober 1913. Konferensi ini membentuk organisasi NVGA (National Vocational Guidance Association). Pembentukan NVGA merupakan toggak awal dalam layanan dan pustaka bimbingan pada sekolah hingga terjadi perubahan organisasi (pembagian cabang asosias) pada tahun 1920. Saat ini NVGA bernama NCDA (National Career Development Association)

Buletin pertama dipublikasikan oleh NVGA dari tahun 1915 hingga 1918 "The Vocational Guidance Buletin" yang berisi medium komunikasi tentang bimbingan vokasional. Tahun 1918 hingga 1921, Buletin berubah "Vocational Guidance Association Buletin" seiring perubahan pada struktur organusasi NVGA . Pada tahun 1924, nama diubah "National Vocational Guidance Magazone". Saat ini, publikasi ini yang diterbitkan berjudul "Journal of Counselling and Development".

Selama Perang Dunia I (1914 -1918), tes Intelegensi (Army Alpha dan Army Beta) dikembangkan dalam membantu merekrut personel. Penetapan tes ini menghasilkan kondisi yang memandang pengukuran sebagai suatu arti dalam 
ketepatan bimbingan. Pergerakan bimbingan dikembangkan didasarkan pada psikometri merupakan cabang dari psikologi dalam memberikan identitas keilmiahan.

Selama kurun waktu ini, tes intelegensi digunakan sebagai instrumen untuk seleksi, penempatan dan pelatihan bagi militer. Sesudah Perang Dunia ke I, instrumen digunakan pada populasi penduduk. Kondisi ini menandakan pergerakan psikometri sebagai salah satu keahlian dalam basis konseling.

\section{c. Pergerakan ilmu bimbingan dan Konseling tahun 1920 -an (Pergerakan Status dan sertifikasi Bimbingan sebagai arah pergerakan)}

Pada awal tahun 1920-an, Generasi kedua pionir, Brewer dan Katherine F.Ball melakukan rangkaian usaha status profesi bimbingan khususnya bimbingan karier pada organisasi dan profesional. Pada organisasi dilakukan penekanan pedoman baru tentang revitalisasi pergerakan bimbingan (khususnya bimbingan karier) pada daerah-daerah. Jangkauan pergerakan bimbingan diperluas dan dibagi untuk menjaga beberapa fungsi dari bimbingan.

Pada saat itu pula, arah pergerakan didasarkan pada kesadaran dalam membangun profesi bimbingan di perkotaan, seperti Newyork mendirikan lembaga sertifikasi bimbingan, Connecticut menyusun perundang-undangan tentang membangun bimbingan vokasional sebagai bagian dari sistem pendidikan pada tahun
1923. Secara tidak langsung, kesepakatan bersama terjadi pada akhir abad ke 20 bahwa pekerja dalam bidang bimbingan harus memperoleh pelatihan khusus dalam melaksanakan tugas.

Pada tahun 1929, Abraham dan Hannah Stone membangun "Margareth Sanger Research Bureau" merupakan pusat pengembangan konseling perkawinan dan keluarga pertama di New York. Abraham Stone (1890- 1959) merupakan seorang urologi yang memiliki minat pada masalah kesehatan reproduksi, rencana pernikahan, kontrol kelahiran, kemandulan, kesuburan, populasi berlebihan global. Istri Hannah (1894 -1941) merupakan seorang dokter yang mendorong dan mendukung gerakan kontrol pada kelahiran. Abraham dan Hannah Stone memberikan konseling pada ribuang pasangan yang mengalami masalah hubungan suami istri dan seksual. Hasil usaha atau pendekatan ini merupakan signifikasi pertukaran praktik bimbingan khususnya konseling bukan hanya pada karier atau vokasional melainkan pada topik atau bidang lain.

Pada akhir tahun 1920-an, kebutuhan bimbingan dalam penyesuaian diri semakin disadari dan proses konseling semakin terlihat pada model yang ditekankan oleh konselor. Saat itu, individu menyadari perlunya proses bimbingan ditambah model konseling yang semakin menarik. Sebagai trend yang berlanjut, bimbingan karier digolongkan dalam bagian bimbingan yang merupakan keseluruhan dari pendidikan seperti halnya bimbingan pribadi dan sosial. Selama proses ini 
bimbingan dilihat sebagai program layanan tambahan di sekolah.

\section{d. Pergerakan ilmu bimbingan dan Konseling tahun 1930 -an (Model Bimbingan dan Konseling Pertama)}

Selama dekade 1930-an, Amerika Serikat mengalami depresi dan keputusasaan. Salah satu masalah yang dihadapkan adalah penempatan pada pekerjaan. Selama kurun waktu ini presiden Roosevelt meminta dan memperoleh dari kongres legislatif tentang mendirikan lembaga "Federal Emergency Relief Act" dalam membangun sistem bantuan federal. Menurut Harry L. Hopkinn, Solusi ini memandang bahwa "bantuan pekerjaan lebih baik daripada memberikan uang". Kemudian didirikan pula "The Civilian Conversation Corps (CCC)" dan "National Youth Administration (NYA)" organisasi yang menerima kaum muda antara 18 tahun hingga 25 tahun yang bekerja diluar kota.

Agensi ini memiliki ini memiliki tugas memperkerjakan kaum muda. Agensi ini diasumsikan sebagai fungsi edukasi, khususnya pada pelatihan vokasional pada pekerjaan tertentu. Depresi ekonomi menyebabkan rencana individu jatuh pada katalismik (bencana) sosial, ekonomi, dan politis dimana kaum muda diperlukan atau difungsikan sebagai perubahan kondisi. Secara umum, agensi ini dikatakan sebagai layanan bimbingan. Menurut survey nasional, populasi yang ditargetkan dan diperoleh hanya melalui layanan bimbingan.
Seiring itu pula pada tahun 1930-an, Asosiasi Pendidikan Progresif melaksanakan suatu rancangan yang mengiring konsep bimbingan pada Sekolah Menengah. Perubahan kurikulum dikembangkan pada pendekatan yang berfokus pada kognitif, afektif, dan sensitivitas sosial. Sedangkan sistem bimbingan disesuaikan pada perkembangan dan penyesuaian diri melalui model Parson (Model Trait an Factor)

Pada tahun 1930-an, Edmund Griffith ("E. G") Wiliamson (1900 - 1979) merupakan seorang akademisi. setelah lulus s3 pada bidang psikologi. Williamson bekerja pada fakultas di Universitas Minnesota saat berumur 31 tahun. Selama tahun 1930-an, Universitas Minnesota telah membangun "the Minnesota Employment Stabilization Research Institute dalam mengembangkan karir selama depresi ekonomi. Williamson mengaplikasikan prinsip-prinsip Parson pada institusi. Pendekatan ini dikenal sebagai "trait and factor theory" atau pendekatan Counselor centered.

John Brewer mempublikasi buku education as guidance. Setiap guru adalah konselor. Bimbingan masuk dalam kurikulum sekolah. Publikasi Dictionary of Ouccupational Titles.

e. Pergerakan ilmu bimbingan dan Konseling tahun 1940 -an (Model Bimbingan dan Konseling Kedua)

Pada tahun 1940-an, pergerakan bimbingan dan psikologi industri mengembangkan literatur pada tes bakat 
pada sumber daya (tenaga kerja dan militer) selama perang dunia ke II. Konseling menjadi bagian integral pada sistem militer selama perang dunia ke II. Konselor diatur pada posisi pos militer dan pusat pelatihan pasukan. Kapten Mitchell Dresse menyatakan "bahwa konseling merupakan hal yang sama dalam membangun kondisi rumah, gereja, sekolah, industri, dan militer. Pada tahun 1944, komitmen pimpinan mayor militer mengembangkan layanan konseling untuk demobilisasi (penurunan status kesiagaan) untuk membantu para veteran menyesuaikan pada kehidupan masyarakat.

Pada tahun 1942, Carl Rogers mempublikasikan buku "Counselling and Psychotherapy. Rogers menekankan pada konseling merupakan hubungan yang lebih sekedar diagnosis. Hal ini mematahkan monopoli obat-obatan dan perawatan dalam psikiatrik. Pandangan Rogers bahwa kepribadian dapat berkembang, berlanjut, dan memiliki pilihan rasional sesuai respon dari konselor pada setiap orang. Asumsi teoritis ini menggemakan pergerakan bimbingan khususnya aspek-aspek bimbingan pada 20 tahun ke depan. Roger mendorong bahwa hubungan konseling ditandakan pada kehangatan dan responsif (mau mendengarkan ) pada setiap bagian dari konselor. Suasana permisif dapat mengantarkan klien /konseli merasakan perasaan yang dapat diungkapkan dan berpikir tanpa paksaan atau tekanan bagi klien / konseli. f. Pergerakan ilmu bimbingan dan Konseling tahun 1950 -an ( Pergerakan Penyatuan Profesional Bimbingan dan Konseling yang berdifferensiasi)

Adanya differensiasi pada bimbingan berawal pada dibentuk organisasi 'National Vocational Guidance Association (NVGA) tahun 1913, National Association of Dean of Women (NADW) tahun 1916, dan National Association of Personnel and Placement Officer (NAPPO) tahun 1924. Pertama kali upaya mempersatukan dilakukan pada kegiatan National Occupational Conference (NOC) di New York pada April tahun 1933 dalam kebersamaan dan keberadaan setiap organisasi profesional bimbingan.

Pada tahun 1934, laporan terakhir penerimaan 7 asosiasi membawa keberadaan yang membawa keberadaan the American Council of Guidance and Personnel Associations (ACGPA). Kelompok organisasi ini memberikan keanggotaan pada Institute of Women's Profesional Relations, National Association of Dean of Women, National Federation of Bureau of Occupations, National Vocational Guidance Association, Personnel Research Federation, Southern Women's Educational, dan Teacher College Personnel Association. Afiliasi organisasi ini diakui dan diterima serta dilaporkan kegiatan aktifitas kepada NVGA. Meskipun konsep federasi (pengabungan) telah diterima, badan ini tidak memiliki pegawai, dana, dan hanya 
bergerak pada kerendahan hati dari anggota-anggota.

Pada tahun 1940, the American Council of Guidance and Personnel Associations (ACGPA) berubah nama menjadi the Council of Guidance and Personnel Associations (CGPA). CGPA merupakan harapan terbaik dalam penyatuan profesional bimbingan namun sejak awal otoritas dibatasi sehingga tidak memiliki kemampuan menggerakkan komitmen dari unsur organisasi kala itu. Pada tahun 1940-an, proses penyatuan profesional bimbingan menjadi kurang diperhatikan selama mengalami krisis nasional selama Perang Dunia ke II.

Pada tahun 13 Juni 1951, NVGA merupakan asosiasi bimbingan tertua di Amerika, berubah menjadi divisi dan berubah nama menjadi the Personnel and Guidance Association (PGA). Kemudian, pada tahun Maret 1952, berubah nama menjadi the American Personnel and Guidance Association (APGA) memiliki 4 divisi, yakni : Divisi pertama, American American College Personnel Association (ACPA), Divisi kedua, National Association of Guidance Supervisors and Counselor Trainers (NAGSCT), Divisi ketiga, National Vocational Guidance Association (NVGA), dan divisi keempat, Student Personnel Association for Teacher Education (SPATE). Organisasi internal ini diterima atau diakui sebagai divisi yang otonom, dan mencerminkan perlunya kompromi dalam membawa satu bendera pada layanan bimbingan yang berbedabeda. Pergerakan bimbingan dan konseling mengalami differensiasi dalam layanan pada kelompok masyarakat tertentu. Fungsi differensiasi membangun area soliditas dalam standar layanan bimbingan. American Personnel and Guidance Association (APGA) didirikan dalam tugas membangun standar minimum pada profesi Bimbingan dan Konseling.

National Defence Education Act (NDEA) didukung dipicu peluncuran Sputnik I. Kesuksesan Uni soviet dalam meluncurkan satelit ke luar angkasa membawa kegelisahan pada sistem pendidikan di Amerika. NDEA merupakan organisasi bimbingan yang memiliki peran strategis dalam membangun kepercayaan diri pada sistem pendidikan di Amerika Serikat.

Teori baru muncul (analisis transaksional, rational-emotive therapy).bersaing dengan teori lama (psikoanalisis, behaviorisme, trait and factor, clent centered). Selama tahun 1950an, teoritis bimbingan mengalami perubahan dari bagian praparadigma proposisi hingga kumpulan representatif teori yang berusaha unggul dalam masa perkembangan ilmu pengetahuan. Selama tahun 1940-an hingga 1950 -an, Aubrey mengumpulkan beberapa rangkaian teori psikologi perkembangan, teori belajar, psikiatri, dan sosiologi dalam memperkuat teori bimbingan. Teori Giznberg (1951) yang memandang bahwa pilihan vokasional merupakan proses yang kumulatif. Teori Roe (1951) tentang pilihan karir berdasarkan pada kepuasan individu. Teori Donald Super (1951) 
memberikan definisi tentang bimbingan karier. John Holland (1959) mempublikasikan tentang "A Theory of Vocational Choice." diasumsikan bahwa individu diyatakan kepribadian berdasarkan pilihan jabatan atau pekerjaan.

\section{g. Pergerakan ilmu bimbingan dan Konseling tahun 1960 -an (Pergerakan Bimbingan dan Konseling Perkembangan)}

Pada tahun 1960-an, Konseling pada perkembangan mendapatkan perhatian. Gilbert Wrenn mempublikasikan "The Counsellor in changing World" mengantarkan perlunya sensitifitas kultur pada Leona Tyler menulis tentang Konseling dan Psikologi Konseling. Konseling Behavioral muncul sebagai teori konselimg yang kuat, diawali dengan "Revolution of Counselling" karya John Krumboltz. Konselor mulai tertarik pada isu sosial dan krisis. Munculnya Community Mental Health Center Act. APGA mempublikasikan kode etik. ERIC Clearinghouse on Counselling and Personnel Services Services (CAPS) didirikan dan mulai membangun database riset mengenai konseling

Peran dan standar training untuk konselor sekolah dibuat. Jurnal The Counselling Psychologist dipublikasikan pertama kali. Dari tahun 1960 hingga 1970, layanan bimbingan dan konseling diperbaharui pada konsep perkembangan yang didorong akuntabilitas, objektifitas dan evaluasi. Hal ini memunculkan model bimbingan dan konseling perkembangan. h. Pergerakan ilmu bimbingan dan Konseling tahun 1970 -an ( Pergerakan Bimbingan dan Konseling Komprehensif )

Pada tahun 1970 -an, diversifikasi konseling di luar setting pendidikan. Derald Sue, editor Personnel and Guidance Journal, memfokuskan perhatian pada isu multikultural. American Health Counselling Association didirikan. Basic helping skills program dilembangkan oleh Allen Ivey. Lisensi dari negara bagian untuk konselor dipopulerkan (Virginia).

Pada tahun 1974, Gysbers and Moore telah menyusun model manual bimbingan dan konseling komprehensif. Model ini memiliki respek yang signifikan, diantaranya sebagai berikut : pertama, terminologi karier yang menggabungkan semua peran individu diasumsikan pada berbagai keadaan semasa hidup, kedua, penggunaan terminologi perkembangan individu yang merupakan proses menjadi sesuatu atau keadaan yang dilalui. Ketiga, karir yang dihubungkan pada konteks kehidupan individu. Keempat, memiliki pandangan holistik pada individu, seperti : kebutuhan fisik, emosi dan keunikan individu.

Banyak usaha yang telah diberikan program bimbingan dan konseling dalam mempermudah perkembangan karier di sekolah. Gysbers and Henderson (2006) mencari jejak tentang tren bimbingan dan konseling di Amerika dari tahun 1910- an hingga tahun 1970, bimbingan dan konseling sebagai layanan tambahan bagi 
peserta didik menjadi program perkembangan

program pemerintahan, dan sistem pendidikan pada abad ke 20. Diharapkan pada artikel ini, konselor dapat menggunakan historis masa lalu dalam menghadapi masa mendatang.

\section{i. Pergerakan ilmu bimbingan dan Konseling tahun 1980 -an ( Diversifikasi Bimbingan dan Konseling )}

Pada tahun 1980-an, APGA berubah menjadi American Association for Counselling and Development (AACD). standar konseling makin berkembang. Pertumbuhan dan perkembangan menjadi fokus konseling (orang dewasa dan lansia, isu gender dan preferensi seksual, perkembangan moral dan multikultural).

j. Pergerakan ilmu bimbingan dan Konseling tahun 1990 -an ( Pergerakan Akuntabilitas, Kode Etik dan Standarisasi Bimbingan dan Konseling )

Pada tahun 1990-an AACD berubah menjadi American Counselling Association (ACA), Isu keberagaman dan multikultural semakin berkembang. isu spiritual mulai diterima.

\section{KESIMPULAN}

Secara formatif, permulaan pergerakan bimbingan dan konseling telah didorong oleh pionir didasarkan pada ideide atau pemikiran sosialisme. Keadaan yang berkembang pada setiap dekade memberikan sumbangan besar dalam perkembangan profesi Bimbingan dan Konseling dalam bentuk organisasi,

\section{REFERENSI}

Brewer, John M. 1942. History of Vocational Guidance, origin and early development. Harper \& Brother : USA.

Blocher, Donald H.2000. The Evolution of Psychology Counselling. Springer : New York.

Leong, Frederick T. 2008. Encyclopedia of Counseling. Changes and challenges for Counselling in the 21 st century. SAGE: USA.

Foxx, Parikh Sejal. Baker, Stanley.B. Gerler.jr, Edwin R. 2017. School counselling in the 21 st century sixth edition. Routledge : Newyork.

Hitchcock, William L. Mabry,N.Kemp. 1971. Readings in Guidance. Georgia Southern College : NewYork.

Picchioni, Anthony Paul. 1980. History of Guidance in the United States. Dissertation of University of Texas : North Texas

https://en.m.wikipedia.org/wiki/Frank_Pars ons_(social_reformer)

https://www.findagrave.com/memorial/161 028756/jesse-buttrick-davis

https://en.m.wikipedia.org/wiki/Clifford_ Whittingham_Beers 
https://www.findagrave.com/memorial/572 23142/eli-witwer-weaver

https://www.timetoast.com/timelines/histor

y-3fdbf3ef-cb3c-40ee-9772-

191ed2173924

Watson, Joshua C \& Schmit, Michael K. 2020. Introduction Mental Health Counselling Contemporary Issues.

SAGE : USA.
Wibowo, Mungin Eddy.2018. Profesi Konseling Abad 21. Unnes Press : Semarang. 